\title{
11
}

\section{Class-Based Communities: The Postcolonial Reform of School Education in South Africa}

\author{
Alex Veit
}

\section{Introduction}

The belated decolonisation of South Africa-more than three decades after the African independence wave of the 1950s and 1960s-created a singular predicament for the newly democratic state. On the one hand, South Africa followed in the footsteps of many independent former colonies and settler-dominated states eager to turn the claims and dreams of the anticolonial struggle into reality. The foremost anticolonial claim in South Africa, as elsewhere on the continent, was deracialisation. As far as schools were concerned, deracialisation in South Africa in 1994 meant offering the oppressed non-white population and the privileged white minority similar educational opportunities, teaching children of all racialised groups in the same schools. "The doors of learning and of culture shall be opened!" proclaimed the 1955 Freedom Charter, which summarised the ANC's postcolonial vision for the country. "Education

\section{A. Veit $(\bowtie)$}

University of Bremen, Bremen, Germany

e-mail: veit@uni-bremen.de 
shall be free, compulsory, universal and equal for all children" (The Freedom Charter 2011).

On the other hand, the decolonisation of South Africa in 1994 took place in a radically different global economic and ideological climate than the independence of its fellow ex-colonies to the north. At the time of Africa's wave of independence between 1956 and 1968, the international political climate was fully favourable to the expansion and extension of public welfare. States in Western Europe and North America as well as in Eastern Europe and the Soviet Union invested steadily in welfare provision, including the education of underprivileged youth. Across the Global South, states from Cuba to South Korea, regardless of their socialist or capitalist overall orientation, embraced state-centric models of development and welfare. Newly independent African states became part of this global climate and invested in free public education (Aina 2004, 12; Mkandawire 2009, 142).

Deracialisation thus meant expansion, and expansion meant much bigger budgets. The bills for this expansion were covered by global economic growth, the nationalisation of major economic assets, and comparatively generous credit facilities and grants. By contrast, South Africa's decolonisation took place during the heyday of global neoliberalism. Across the globe, the commodification of welfare, including the marketisation of school education, was one important element in a larger context that promoted the privatisation of state assets and fiscal austerity. Most former colonies underwent severe economic crises and implemented "structural adjustment programmes" that cut deeply into education budgets. International credit and grants had become scarce. Moreover, economic growth was stalling globally, putting the brakes on South Africa's export-oriented industries.

For South Africa's school education policies, the conflicting demands of a postcolonial welfare expansion and a neoliberal welfare contraction posed a substantial quandary. The democratic government inherited a racially divided public school system, which provided well for the white minority, but offered only dismal education facilities to the large majority of citizens. In this contribution, I aim to analyse the attempts made to square the circle of postcolonial and neoliberal imperatives. 
My focus here lies on the political ideas and options discussed in South Africa in the transitional period, which also took up, mirrored and responded to transnational political discourses of the time. Deracialisation and neoliberalism have been dominant, but contradictory elements in South Africa. A third programmatic and globally significant line of thinking complements the contradiction between deracialisation and neoliberalism, namely concepts of "community" and communitarianism.

In the Anglophone world, the idea of "communities" as both engines of change and guarantors of social cohesion can be traced back to the British colonial invention of "community development" (Smyth 2004), for example. Various thinkers have tried to come to grips with the term's analytical value and empirical meaning (Elias 1974).

Communities, while usually understood to imply groups of people enjoying geographical proximity, mutual affection and commitment, and a set of shared values, are summarised by Kymlicka $(2002,208)$ as a mere ideal appearing in "different forms, from class solidarity or shared citizenship to a common ethnic descent or cultural identity," serving to produce, transmit, justify and enforce "shared conceptions of the good" (Etzioni 2016, 1).

Communitarianism, as a political philosophy, is a set of different, often contradictory ideas rather than a coherent school. Nonetheless, debates about communitarianism attracted attention in the 1980s. As Miller (2000) suggests, three broad political variations exist, each conceptualising communities differently: liberally, as value-based voluntarist groups whose members take part in a plurality of communities; conservatively, as an inclusive group whose members are born into rather than voluntarily join the group, which plays a crucial role in preserving social cohesion and hierarchy; and on the progressive left as associations of materially and politically equal citizens engaging democratically in collective self-determination.

In South Africa, these different conceptions of community played a role throughout the twentieth century. Especially in the decade before and during the transition (1990-1994/96), the term "community" in South Africa became used as ubiquitously as elsewhere in the Anglophone world. And while it meant different things to different people, one common denominator was the idea of shifting power from centralised state 
institutions to local, nonstate institutions. This promise cushioned the anxieties of white middle-class parents facing a first black-majority government. It also inspired progressive antiapartheid activists who had been tormented by the all-powerful militarised state and now hoped for the democratisation of society on all levels.

During South Africa's decolonisation, the idea of community-run schools served to reconcile the contradictory demands of economic neoliberalism and political deracialisation. Schools formerly reserved for the white population were officially deracialised; however, school fees determined by school communities effectively excluded the poor (and overwhelmingly non-white) population. While the progressive and liberal variations of communitarianism in particular promised empowerment through the devolution of power, in South Africa's apartheid-shaped structures school communitarianism reproduced segregation. Race, as a category of exclusion, was replaced by class. This arrangement worked well for both the white and the emerging non-white middle classes, which as "school communities" gained the right to shape "their" schools.

\section{Setting the Path: Neoliberalism and Communitarianism in the Late Apartheid Period}

In the second half of the 1970s, South Africa's racialised school education system, like the apartheid system in general, experienced a profound crisis that was driven by two interconnected dynamics. First, the apartheid state had radically underfunded the schools of the non-white majority. Beginning in the 1960s, however, there was a lack of skilled workers for the country's growing manufacturing sector. The educative marginalisation of the majority turned into an impediment for industrial growth. From 1972 onwards, the government opened more secondary schools (while preserving racialised segregation between the schools), and also put them on a slightly sounder economic basis. The ratio of monetary expenditure for white and African children decreased from 18:1 to 15:1. 
Nonetheless, schools for the non-white population remained severely overcrowded and underfunded (Hyslop 1999, chap. 7).

The rejuvenated resistance movement was a second factor. In 1976, anger about apartheid in general and the education system in particular exploded in the Soweto student uprising. Secondary school students became central actors in the opposition, and schools became central sites of struggle. Throughout the 1980s, recurring national school strikes shattered the non-white education system in the townships. Inside the resistance movement, discussions about the costs of unlimited school boycotts ensued. While the camp arguing for "Liberation before Education" prevailed, the political conflict had devastating and enduring consequences for the existing schools in African townships (Hyslop 1999, chap. 8-9).

To counter the deepening crisis, the regime gradually phased out its state-centric development model as well as its most blatant racism, and instead embraced neoliberal concepts pursued by governments in the USA, the UK and elsewhere. In the education sector, the Department of Bantu Education responsible for the education of Africans outside the homelands was renamed Department of Education and Training (DET) in 1984. The human capital approach, which understands education as an economic investment, became the new leitmotif. Pupils would be channelled into academic institutions, technical schools or directly into the job market according to their "capacities." Given the vastly different quality of education provided at an early stage, this arrangement preserved the racialised educative hierarchy with reference to merit rather than biological racism (Chisholm 2002, 98-101). At the upper end of the education hierarchy, the government recognised the contribution of private schools, which before had been viewed with suspicion, and afforded them state subsidies (Du Toit 2003, 382-83).

Another ideological trait gaining traction both in South Africa and across the globe was communitarianism as the idea that "communities" rather than a central authority were best placed to organise social life. As early as the late 1940s and 1950s, the apartheid regime had developed conservative communitarian notions of European and "Bantu communities" (Levy 2011, 177-81), which were to be educated separately for their own good, as their different "levels" of development demanded discriminate treatment (Dubow 1992, 231-32). Such conceptions borrowed 
from and responded to transnational ideas of modernisation, development and scientific judgement (Kros 2010).

Reforms introduced in 1984 aimed to modernise this system of segregated learners. Primarily, the reforms created many more institutions, each tasked with providing school education for a racialised "community," divided between the white, Indian and coloured populations, the ten ethnically defined homelands or Bantustans (formally autonomous or independent states), and the DET for the mostly urban African population outside the Bantustans (Christie 1990, 38; Chisholm 2012, 87-88).

The ANC and the liberation movement meanwhile increasingly embraced the progressive communitarian discourse of decentralised governance, and sought to mobilise "grassroots" groups in collective action against the regime (Hirson 2017). During the 1970s and 1980s, the ANC's leadership in exile was heavily exposed to the communitarian thought and community development discourse popular in their host countries, especially in the United Kingdom and Anglophone African countries. Inside the country, the United Democratic Front-the major opposition organisation closely related to the outlawed ANC_-similarly embraced a social movement approach based on the notion of community organisation. Crucially, Parent Teacher Student Associations attempted to use schools as a site of political mobilisation, while also developing postcolonial forms of education (Karlsson et al. 2019, 154). These discourses and practices obviously were radically different from the racialised communitarianism of "self-government" espoused by apartheid ideologues. The principle of involving school members in democratic decision-making, however, was not that far away from the neoliberal notion of "stakeholders" participating in governance processes. Once apartheid's racist discourse had become politically unacceptable, the liberal and progressive notion of community became a common ground for viewpoints that originally diverged widely from one another. 


\section{Model C: A South African Third Way}

The ideological marriage of neoliberalism and communitarianism continued to inform school reforms during the introduction of the postcolonial democracy. In 1990, the government agreed to negotiate a transition. The days of racially segregated schools obviously were numbered. The prevalent educational concern among the non-white population was the attainment of quality education. Among the privileged white population, it was the loss thereof. These concerns brought the top end of the public school system, the schools so far reserved for white students, into focus. Their reform by the outgoing apartheid government proved decisive for the postcolonial period.

In the spirit of devolving power to school communities, in 1991 the outgoing government's education ministry allowed white state schools to select their future status by a parents' vote. All options included a clause opening the schools to a limited number of non-white pupils. The choice menu included full privatisation (Model A), continuance as a state school (Model B), or semi-privatisation (Model C). Model C proposed the transfer of school real estate and buildings from the state to the school, to be administered by a school-governing body (SGB). Effectively, this constituted an embracing of liberal over racialised notions of community. School budgets would be covered by a state subsidy (at the time, about 80 percent of operational costs), user fees paid by parents and other school-generated income. After the parents proved slow to embrace change, in 1992 the government issued a decree turning all white state schools into Model C schools if parents had not voted against this. By April 1992, 96 percent of white schools had changed to Model C (Christie and McKinney 2017, 9; Karlsson et al. 2019, 146).

The ANC initially rejected this decisive reform of the outgoing government. At the same time, the ANC found itself in a period of transformation from liberation movement to the governing party and had no ready-made alternative policies to hand. Beyond public criticism, the ANC did not attempt to stop or change Model C during the negotiation period. After all, the reform also began with the racial desegregation that was of crucial importance to the ANC, and the imminent 
democratisation of the political system would include an overhaul of the school system as a whole in any case.

This democratic, postcolonial overhaul began with the 1994 interim constitution, which abolished the various racialised ministries and departments of education in favour of national and provincial administrations and culminated in the South African Schools Act No. 84 of 1996. In the discussions about the Act, for an extended period, it seemed that the elected government would reverse Model $\mathrm{C}$ semi-privatisation. The ANC-led Department of Education argued as late as 1996 that Model C "ensured a perpetuation of substantial advantages and privileges," such as the best facilities and most highly qualified teaching staff, to those groups "who had historically been most advantaged by the policy and practise of racial preference in this country" (Department of Education 1996).

Besides a large number of different stakeholders involved in the contentious policy-making process, two foreign consultants are ascribed a major influence, especially concerning the maintenance of a semiprivatised, community-run school system. Christopher Colclough, a British academic working on education and development, and Luis Crouch, a US expert in the economics of education, provided "perhaps the most persuasive case for school fees" (Fiske and Ladd 2010, 136), arguing that the quality of former white schools would deteriorate if fees could not be used to hire teachers and maintain facilities. They predicted that "key opinion- and decisionmakers" would move their children into the private school system. Future governments, uncontained by a powerful civil society group interested in quality public education, would hardly invest appropriately when resources were scant. The public system's quality, catering only for the poor, would continue to deteriorate. The solution was fees used to keep the middle class in the public system. Resulting savings in the state budget could be invested in schools in former homelands and townships. Fees, originally regarded by the ANC as detrimental to those who could not afford to pay, would then actually help to raise up the poor (Fiske and Ladd 2010, 136-37; Jansen 2001, 276).

The 1996 Schools Act, which formally ended Model C, expanded many of its features to the national public school system. Crucially, it allowed schools to set an individual fee structure. Enormous differences 
between schools developed: while especially schools in the most impoverished rural areas, the former homelands, charged either very low fees or none at all, the leading Model C primary schools in the mid-2010s would often charge around 25,000 Rand per year (about 2,000 US dollars at the time) (Businesstech 2016). In 2015, this amounted to 18 percent of the average South African household's annual income, but less than 6 percent for white households, and almost 27 percent for the average black household (average household incomes according to Stats SA 2017, 14).

To counter the resulting educational inequality between rich and poor and white and nonwhite students, a 1998 provision exempted poor households from fee payments (Fiske and Ladd 2004, 65). In 2006, schools were allowed to apply for additional public funding and become fee-free schools (Ahmed and Sayed 2009). Primarily schools with a poor student population qualified for increased funding and moved back fully into the state fold. This restructuring reproduced the pre-existing bifurcation between semiprivate, community-run schools on the one hand and fully funded public schools on the other.

The politics of continuity, despite the ANC's commitment to postcolonial equality, reflected the country's complex economic and social legacy and the new governing party's complicated relationship with different groups. Inside the ANC's core constituency, the non-white population, class divisions emerged. Diverging class interests needed to be addressed without being formally acknowledged. Beyond its electoral constituency, the ANC government also sought to uphold the compromise solution at the root of the postcolonial transition and find common ground with the business sector interested in highly skilled workers, the white middle class who still made up the best-educated strata of the workforce, and not least the administrative apparatus inherited from the previous regime that kept the state machine going. Charging fees from those who could afford them freed up scarce public resources to be spent on the education for the poor-effectively a promise to raise the quality of schools for the poor to the level of former white schools in the distant future-while reassuring the old and the new middle classes in the immediate present. The retention of Model $\mathrm{C}$ allowed the new political elite and the "emerging black middle class, including legislators and officials, to silently permit their 
own class interests to be taken care of without confronting (or clashing with) their own, largely poor, constituencies" (Karlsson et al. 2019, 150).

The break with earlier promises and the ongoing glaring educational inequality resembling the social structures established by the apartheid system called for a legitimating angle acceptable to a wide array of constituents and partners. The overlaps between different communitarian variations provided the ideological glue between these diverse groups and constituencies, as well as between postcolonial and neoliberal ideals and ideas. The structural epitome of this convergence is the school-governing bodies (SGBs) introduced in Model C schools, which resemble the parent teacher student associations born in the antiapartheid struggle. The extension of SGBs across the public school system in 1996 was "surprisingly uncontroversial," as they built on the shared ideal of school community self-government (Karlsson et al. 2019, 154). Their ability to use fees to improve school attractiveness allowed schools with a wealthy parent body effectively to shield their educational advantage against the poor, overwhelmingly non-white population. In poor communities, SGBs worked much less effectively, as parents lacked the time and capacity to engage with schools.

\section{Conclusion}

The story of the persistence of Model C schools highlights the importance of global historical timing for postcolonial social policy. The belated deracialisation and democratisation of South Africa posed a question similar to other decolonisation projects: how to achieve both equity and quality in the school system? In the first three decades after World War II, both the discourses and structures of the international system allowed newly independent states to pursue a vision of free public schooling. By 1994, discourses and structures had fundamentally changed. Political discourse favoured a much-reduced role of the state and the marketisation of education. Economic stagnation added material authority to ideology: losing newly won sovereignty to international financial institutions was a threat that loomed over the incoming postcolonial government. Communitarianism, an increasingly influential concept both inside the 
country and internationally, provided a compromise between different expectations and approaches: it made it possible to impose a fee on the middle class that could be understood as a tax, while in return devolving power to emerging class-based school communities.

These school communities changed over time. The attractiveness of former Model C schools among the striving non-white middle classand among some poor parents who would make additional sacrifices to send their children there-changed these schools' composition over time (Msila 2005; Hunter 2010). Today, former Model C schools are the schools that most closely resemble the country's overall "racial" demography. At the extreme ends of the spectrum, meanwhile, are the much more expensive private schools with an overwhelmingly wealthy and white student body, and the struggling schools in former townships and especially in former homelands, whose students are almost uniformly non-white and poor.

Acknowledgements This chapter is a product of the research conducted in the Collaborative Research Center "Global Dynamics of Social Policy" at the University of Bremen. The centre is funded by the Deutsche Forschungsgemeinschaft (DFG, German Research Foundation)—project number 374666841-SFB 1342.

\section{References}

Ahmed, Rashid, and Yusuf Sayed. 2009. Promoting Access and Enhancing Education Opportunities? The Case of 'No-fees Schools' in South Africa. Compare: A Journal of Comparative and International Education 39 (2): 203-218.

Aina, Tade Akin. 2004. How do we Understand Globalization and Social Policy in Africa? In Globalization and Social Policy in Africa, ed. Tade Akin Aina, Chachage Seithy Chachage, and Elisabeth Annan-Yao, 1-20. Dakar: Codesria. Businesstech. 2016. Best Private and Public Schools in South Africa: Cost vs Performance, sec. Lifestyle. February 9. Accessed August 12, 2020. https://businesstech.co.za/news/lifestyle/111863/best-private-and-publicschools-in-south-africa-cost-vs-peformance/. 
Chisholm, Linda. 2002. Continuity and Change in Education Policy Research and Borrowing in South Africa. In The History of Education Under Apartheid 1948-1994: The Doors of Learning and Culture Shall Be Opened, ed. Peter Kallaway, 94-108. New York: Lang.

- 2012. Apartheid Education Legacies and New Directions in PostApartheid South Africa. Storie Delle Donne 8: 81-103.

Christie, Pam. 1990. Reforming the Racial Curriculum: Curriculum Change in Desegregated Schools in South Africa. British Journal of Sociology of Education 11 (1): 37-48.

Christie, Pam, and Carolyn McKinney. 2017. Decoloniality and 'Model C' Schools: Ethos, Language and the Protests of 2016. Education as Change 21 (3): $1-21$.

Department of Education. 1996. Education White Paper 2: Organisation, Governance and Funding of Schools. Notice 130 of 1996. Pretoria: Department of Education. Accessed March 11, 2021. https://www.education.gov.za/ Portals/0/Documents/Legislation/White\%20paper/white\%20paper\%202. pdf?ver=2008-03-05-111655-000.

$\mathrm{Du}$ Toit, Jacques. 2003. Independent Schooling. In Human Resources Development Review 2003: Education, Employment and Skills in South Africa, 380-395. Cape Town: HSRC Press.

Dubow, Saul. 1992. Afrikaner Nationalism, Apartheid and the Conceptualization of 'Race'. The Journal of African History 33 (2): 209-237.

Elias, Norbert. 1974. Towards a Theory of Communities. In The Sociology of Community: A Selection of Readings, ed. Colin Bell and Howard Newby, ixxli. London: Frank Cass.

Etzioni, A. 2016. Communitarianism. In The Blackwell Encyclopedia of Sociology, ed. George Ritzer, 1-8. New York, NY, USA: Blackwell Publishing.

Fiske, Edward, and Helen Ladd. 2004. Balancing Public and Private Resources for Basic Education: School Fees in Postapartheid South Africa. In Changing Class: Education and Social Change in Post-Apartheid South Africa, ed. Linda Chisholm, 57-88. London: Zed Books.

- 2010. Elusive Equity: Education Reform in Post-Apartheid South Africa. Washington: Brookings Institution Press.

Hirson, Baruch. 2017. Yours for the Union: Class and Community Struggles in South Africa. London: Zed Books.

Hunter, Mark. 2010. Racial Desegregation and Schooling in South Africa: Contested Geographies of Class Formation. Environment and Planning A: Economy and Space 42 (11): 2640-2657. 
Hyslop, Jonathan. 1999. The Classroom Struggle: Policy and Resistance in South Africa, 1940-1990. Pietermaritzburg: University of Natal Press.

Jansen, Jonathan. 2001. Explaining Non-Change in Education Reform After Apartheid: Political Symbolism and the Problem of Policy Implementation. In Implementing Education Policies: The South African Experience, ed. Jonathan Jansen and Yusuf Sayed, 271-292. Cape Town: University of Cape Town Press. Karlsson, Jenni, Gregory McPherson, and John Pampallis. 2019. A Critical Examination of the Development of School Governance Policy and Its Implications for Achieving Equity. In The State, Education and Equity in PostApartheid South Africa, ed. Enver Motala and John Pampallis, 139-177. London: Routledge.

Kros, Cynthia. 2010. The Seeds of Separate Development: Origins of Bantu Education. Pretoria: Unisa Press.

Kymlicka, Will. 2002. Contemporary Political Philosophy: An Introduction. Oxford: Oxford University.

Levy, Norman. 2011. The Final Prize: My Life in the Anti-Apartheid Struggle. Cape Town: South African History Online.

Miller, David. 2000. Communitarianism: Left, Right and Centre. In Citizenship and National Identity, 97-109. Cambridge et al.: Polity Press.

Mkandawire, Thandika. 2009. From the National Question to the Social Question. Transformation: Critical Perspectives on Southern Africa 69 (1): $130-160$.

Msila, Vuyisile. 2005. The Education Exodus: The Flight from Township Schools. Africa Education Review 2 (2): 173-188.

Smyth, Rosaleen. 2004. The Roots of Community Development in Colonial Office Policy and Practice in Africa. Social Policy \& Administration 38 (4): 418-436.

Stats SA. 2017. Living Conditions of Households in South Africa. An Analysis of Household Expenditure and Income Data Using the LCS 2014/2015. Statistical Release P0310. Pretoria: Statistics South Africa. Accessed August 12, 2020. http://www.statssa.gov.za/publications/P0310/P03102014.pdf.

The Freedom Charter. Adopted at the Congress of the People, Kliptown, on 26 June 1955. 2011. South African History Online. Accessed August 19, 2020. https://www.sahistory.org.za/article/freedom-charter. 
Open Access This chapter is licensed under the terms of the Creative Commons Attribution 4.0 International License (http://creativecommons.org/ licenses/by/4.0/), which permits use, sharing, adaptation, distribution and reproduction in any medium or format, as long as you give appropriate credit to the original author(s) and the source, provide a link to the Creative Commons licence and indicate if changes were made.

The images or other third party material in this chapter are included in the chapter's Creative Commons licence, unless indicated otherwise in a credit line to the material. If material is not included in the chapter's Creative Commons licence and your intended use is not permitted by statutory regulation or exceeds the permitted use, you will need to obtain permission directly from the copyright holder.

(c) (i) 